Original Research Paper

\title{
A Resource Conservation Technology for Adapting Argroecosystems to the New Natural Conditions of a Warming Climate in South-Eastern Kazakhstan
}

\author{
Naziya Suleimenova*, Dastan Kalykov, Baglan Makhamedova, Zhuldyz Oshakbaieva and Yerzhan Abildayev \\ Kazakh National Agrarian University, Almaty, Kazakhstan
}

\author{
Article history \\ Received: 13-11-2020 \\ Revised: 04-05-2021 \\ Accepted: 06-05-2021 \\ Corresponding Author: \\ Naziya Suleimenova \\ Kazakh National Agrarian \\ University, Almaty, \\ Kazakhstan \\ Email: naziya44@gmail.com
}

\begin{abstract}
This article presents the results of research aimed at developing a resource conservation technology for the adaptation of the soybean agroecosystem to the new natural conditions of a warming climate. In particular, measures to combat drought have been studied: The efficiency of soil-protecting technology (Mini-till) and minimization of anthropogenic impact on soil, the effective use of soil moisture and its impact on soybean productivity. Given: -The estimation of changes in climatic parameters on the average annual air temperature by months of the 12-year duration, - the impact of changing climatic parameters (aridity, dry winds, drought risk) on the ecological situation of the agroecosystem and the development of ways of adaptation of soybean cultivation to the changing climatic conditions of South-Eastern Kazakhstan. During the study of this problem, experimental research was carried out according to generally accepted classical methods: Experiment and observation. The analysis of multifactorial field experience was accompanied by numerous observations, surveys and laboratory analyses. Obtained experimental materials were processed using statistical methods. The warming of the climate is a remarkable phenomenon as the value of average annual air temperature indicates a slight global change, where the anomaly of average annual temperature (reaches a maximum of 8.8 to $11.7^{\circ} \mathrm{C}$, which exceeds the long-term value $\left(7.7^{\circ} \mathrm{C}\right)$ ) shows the global warming of the climate in conditions of cultivation of the valuable leguminous crop, soybean. Based on the received results, the ecological (preservation and restoration of soil resources) and economic efficiency of agroecosystem of soil-protective methods of soy cultivation technology depending on the influence of emerging climatic conditions for 20152018 was determined. The improvement of ecological conditions of soybean agrophytocenosis was revealed, as it depends on the use of soilprotective practices that mitigate the risk of drought in years with high temperatures. It provides optimal crop growth and development with an increase in soybean productivity of up to $23.8 \%$.
\end{abstract}

Keywords: Technology, Resource Conservation, Adaptation, Risk, Agroecosystem, Soybean, Natural Resource, Climate Warming

\section{Introduction}

In recent years, there have been far more dangerous weather events than there were 30 years ago. Many agricultural producers feel the effects of climate change, especially as Russia and Kazakhstan are warming faster than the rest of the world. While there are advantages to this, such as the expansion of crops, there are more disadvantages (Kulistikova 2019). Traditionally, climate change on the planet has been associated and identified with global warming-the increase in the annual average surface air temperature across the globe. However, global warming is only one of the manifestations of climate change (Kiselev, 2019). Simultaneously with the warming, changes are occurring in the hydrological regime (location, duration and intensity of precipitation), circulation patterns of air masses in the atmosphere and water in the oceans, as well as all kinds of weather anomalies, primarily wind 
patterns (hurricanes, tornados, typhoons, etc.); heat/cold waves are becoming much more frequent.

To obtain a more accurate long-term assessment of the impacts of global climate change, (Cline, 2007), it is necessary to determine the likely impact on the development efficiency of agricultural production in a particular country or region. For example, in the conditions of South-Eastern Kazakhstan (Kenenbaev et al., 2019), problems in identifying the probability of climate warming were investigated and the impact of irrigation regime and new varieties on soybean productivity was studied. At the same time, accelerated development of new soybean varieties with shortened crop growing season is followed by water conservation (when testing resource conservation technology (Yelnazarkyzy et al., 2019)) in real conditions of temperature increase in the years of the study.

Modern biological and geographical science has accumulated a large amount of factual material (Dronin, 2014; Perevedentsev et al., 2011; Solomon et al., 2007) and developed conceptual approaches to the problem of climatic impact on the environment. In accordance with trends established by climatologists (Ivanova and Kiryushina, 2009; Schwartz and Kokorin, 2001), the most important climate-related event at present is the so-called global warming, which has been especially pronounced since the late $1980 \mathrm{~s}$. This event puts forward the problem of global changes in the natural environment under the influence of climate change.

In the last decade, the problems of climate change on the planet (Gruza and Rankova, 2003; Bautin, 2011) were increasingly discussed, since this factor significantly affects the formation of crop yields.

In the national report of the Republic of Kazakhstan on the UN Framework Convention on Climate Change published in 2013, experts concluded that over the past 70 years, an increase in the average annual and seasonal surface air temperatures has been observed throughout Kazakhstan (QazaqZerno, 2020).

The process has been particularly fast since the 1980 s (Israel, 2002), which led to large repeatability of warm years. However, the amount of precipitation from the 1940 s to 2011 remained virtually unchanged.

In the 21 st century, according to weather forecasters, warming should be expected throughout Kazakhstan. The forecasted change in the average annual air temperature by 2030 will be in the range of 1.5-1.7 degrees and by 2085, the temperature increase may reach 2.7-4.7 degrees. The east of Kazakhstan and the Almaty region (Suleimenova et al., 2017) are suffering from such a change. The eastern and southeastern territories of Kazakhstan may be affected to a greater extent, due to changes in nature.

All kinds of natural disasters are possible, especially in the mountains: Landslides, mudslides, avalanches, floods, hurricane winds, hail, rainfall, frost and drought.
Experts (Cline, 2007) indicate that the Almaty region is most affected by extreme events. Almost every second case occurs in this region: Heavy rains, wind, snow and snowstorms. Moreover, a significant increase in precipitation is not predicted, which increases the likelihood of drought and the possibility of desert lands spreading out to the north (Gruza and Rankova, 2003).

At the same time, the climate largely determines the interannual variability of productivity and gross yield, as a territorial structure result of national and worldly agricultural production regarding the effects of global warming vary. Therefore, there are many scenarios for the development of the industry based on accelerating plants' growth (Shelamova, 2013). Experts' forecasts (Gritsyuk, 2010; Gritsyuk and Bachishina, 2016; Popytchenko, 2009; Kattsov et al., 2011), changing yields and production stability, changing sown areas, a set of crops and agricultural specialization, transformation of agricultural technology, etc. In addition, global climate change presents a complex problem, covering various aspects of the country's environmental, economic and social development.

Many hypotheses of natural and climatic changes are contradictory due to the great uncertainty of many natural changes, complexity and ambiguity of scientific developments and insufficiency of scientific developments in this area (Volodin et al., 2013; Suleimenova et al., 2019). Hence, there is a need to assess possible consequences in agriculture from climate change and to develop a set of measures for adapting the agricultural sector to changing environmental conditions, minimizing climate impact on crop cultivation.

Analysis of the "climate-agriculture" system highlights two aspects: "Climate as a natural resource" and "climate as a risk for products producers". In this regard, we formed two areas of research: -One of them is associated with assessing the impact of changes in climate parameters, -the second, with assessing the impact of risks' sources for agriculture South-Eastern Kazakhstan. The concepts of "slow changes" and "risk changes" do not exclude, but complement each other in solving the problem of identifying new crop distribution and gross crop production functions due to climate change (Polyanskaya and Polyanskiy, 2014).

Long-term changes in temperature, precipitation and extreme events, such as droughts, flooding, etc., are especially important for agriculture. The impact of relatively rare extreme events on crops leads to economic stress, which requires accelerating research on the problem of adapting agriculture to climate changes (Ivanova and Kiryushina, 2009). Adaptation of measures for the development of agriculture to climate changes should be an important principle in these new conditions. At the same time, the transition to sustainable development under global climate change and the formation of a green economy (Bobyleva et al., 2019) are priority tasks, both for Russia and Kazakhstan and at the global level. 
This paper analyzes the 2015-2018 climate-agriculture system and highlights two aspects: "Climate as a natural resource" and "climate change as a risk for the agroecosystem". We aimed to study the impact of climate change on the yield of the leading grain legume oilseed crop of the zone (soybean) and the possibilities of its adaptation in the conditions of South-Eastern Kazakhstan. The first is to assess the impact of changes in climatic parameters (aridity, dry winds, increased physical evaporation of soil moisture) and the second is to identify the impact of the existing source of risk on the cultivation of soybeans. The resource conservation technology for adaptation of agroecosystem to new natural conditions of a warming climate was developed. Particularly, the following drought management measures were studied: Soil-protective technology-minimization of anthropogenic impact on soil and its impact on the productivity of soybeans.

The objective of this article is to develop resource-saving technology of adaptation of soybean agroecosystem to new natural conditions of the warming climate of South-Eastern Kazakhstan and to study and evaluate parameters of the climate change and technology of rational use of land resources of soybean agroecosystem.

\section{Materials and Methods}

Experiments were carried out in 2015-2018 on the territory of the educational and experimental farm "Agrouniversity" of the Kazakh National Agrarian University, located on the foothill plain of the northern slope of the Ili Alatau (Fig. 1).

Soil distribution and formation of climate features in the region are subject to the law of vertical zonality
(Saparov, 2014). The research area (FSAR, 2005) is characterized by a sharply continental climate, low air humidity, abundance of sunlight, short but moderately cold winters. To characterize the meteorological conditions of the experimental site, we took the data of meteorological conditions for the weather station at the Airport and Issyk. The weather station is located on the same level as the experimental site and reflects its conditions well. The average annual precipitation is $540 \mathrm{~mm}$. About $300 \mathrm{~mm}$ of precipitation falls during the warm season. The average annual air temperature ranges within $7.7^{\circ} \mathrm{C}$.

Field experiments were conducted on meadowchestnut soils of heavy mechanical composition, which are characteristic types of foothill strip in southeast Kazakhstan (Eleshev, 2014).

The humus content is $4.40-4.45 \%$, gross nitrogen $0.12 \%$ and the gross phosphoric acid content in the humus horizon is $0.14-0.19 \%$, which characterizes the lowpotential level. The meadow-chestnut soil has a $\mathrm{PH}=7.3$. Thus, the meadow-chestnut soil by its water-physical properties and the level of potential fertility fully satisfies the conditions of cultivation of all types of crops, including oilseeds of soybeans. The subject of the research was the soybean variety Eureka.

Study and justification of resource conservation technology of soybean agroecosystem-minimization of tillage according to the scheme (Table 1).

The experiments were laid out and repeated three times (Table 1). The variants were arranged in a randomized arrangement. Total plot size $100.0 \mathrm{~m}^{2}(20.0$ $\mathrm{m} \times 5.0 \mathrm{~m})$, recording plot area $57.6 \mathrm{~m}^{2}(16.0 \times 3.6 \mathrm{~m})$ (Fig. 2 and 3).

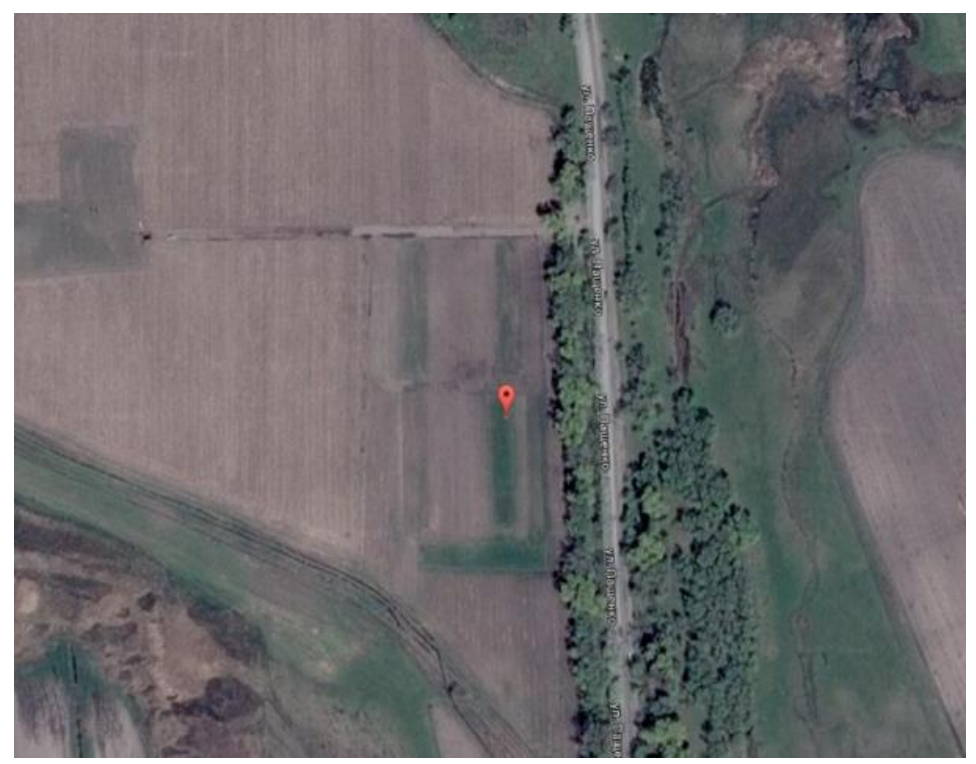

Fig. 1: Site coordinates marked on the map of Saimasay village, study-and experimental farm "Agrouniversity" $43025 / 57,9 / / \mathrm{N} 77019 / 50.7 / / \mathrm{E}$ 


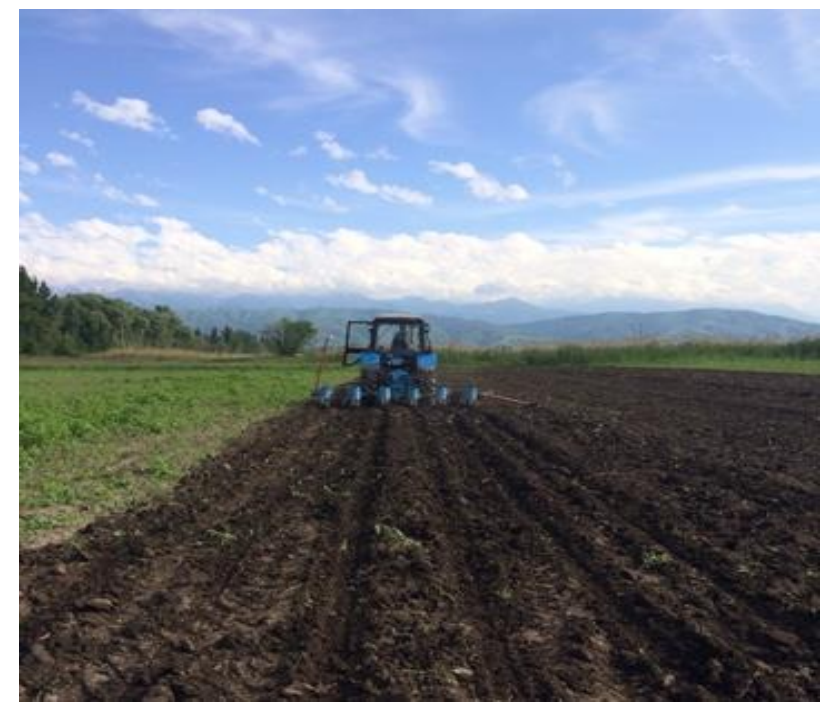

Fig. 2: Setting up a field trial

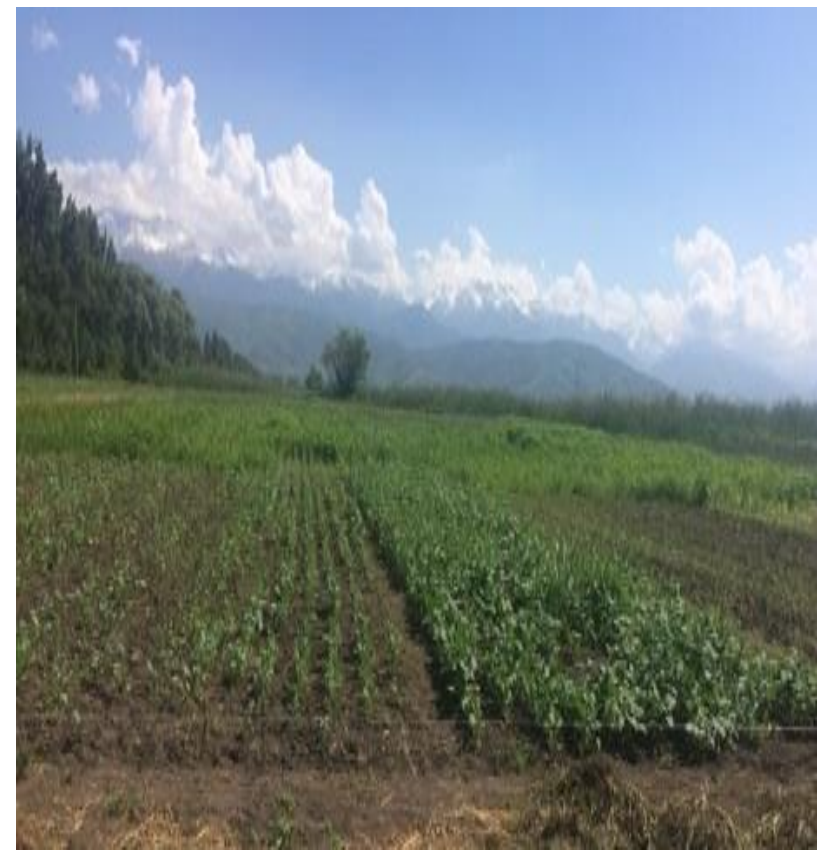

Fig. 3: Sowing soybeans

Table 1: Study and justification of resource conservation technology of soybean agroecosystem-minimization of tillage according to the scheme

\begin{tabular}{lll}
\hline Experiment variants & Technology & Main tillage \\
\hline 1-variant & Traditional technology & Plowing the soil to a depth of 20-22 cm (PN-5-35) \\
2-variant & Resource conservation technology & Boardless tillage at depths of 16-18 cm (KPP-2.2)+herbicide \\
3-variant & Boardless tillage of the soil at the depth of 12-14 cm. 12-14 cm \\
& $($ KPP-2.2) +impulse, at a dose of 0.7 1/ha \\
\hline
\end{tabular}

The main research methods were the generally accepted classical techniques: Experiment and observation. The field experiments were set according to the methodology of experimentation (Novikov and Novikov, 2010) and the methodology of agrotechnical field experiments with oil-bearing crops (Lukomets, 2007). This multifactorial field experiment was accompanied by numerous observations, measurements and laboratory analyses (Kiryushin et al., 2009; Ivanov, 2008; ARWFRI, 2011). 


\section{Results}

Many forecasts highlight the negative effects of global change on agriculture. There is a significant change in weather conditions in traditional agricultural areas, which suggests that the climate will not only be warmer but also drier.

Climate change and its impact on the productivity of agricultural production in the southeast of Kazakhstan were studied in the climate-agriculture system and two aspects were identified: "Climate as a natural resource" and "climate change as a risk for agricultural production".

Climate warming in the territory of the Republic of Kazakhstan turned out to be noticeably larger than global. Anomalies in the average annual temperature during the years of research in the southeast of Kazakhstan reach 3 and $4^{\circ} \mathrm{C}$ (according to 2006 data, $3.5^{\circ} \mathrm{C}$ and 2017 data, $4^{\circ} \mathrm{C}$ ), while for the globe they only slightly exceed $1^{\circ} \mathrm{C}$ (Fig. 4).

The average annual air temperature exceeds the average long-term value in the study area and varies between 8.8 and $11.7^{\circ} \mathrm{C}$ with an average long-term value of the territory of $7.7^{\circ} \mathrm{C}$.

In research areas, almost one-third of the annual precipitation falls during April and May. The number of days with precipitation in these months reaches 10-14. The temperature rises sharply during days without precipitation. However, despite the increased temperature background, due to frequent rains, the hydrothermal coefficient in spring is high and amounts to 2.0-3.8, which characterizes the high seasonal rainfall in the region. In parallel with precipitation, in April the maximum air temperature can reach up to $+30^{\circ} \mathrm{C}$ and in May $+35^{\circ} \mathrm{C}$.

The obtained results of determining climate change rationale prove the general tendency of climate change, which can be characterized as "warming with increasing aridity" within the scope of our research.

If we build a four-dimensional gradation of changes in climate parameters over a 12-year study with an increase in air temperature by $1^{\circ} \mathrm{C}$, it is revealed that in all years of the study, the change in air temperature exceeded $1^{\circ} \mathrm{C}$, i.e., there is not a single year where the typical average long-term value of the air temperature of the study area would not exceed this value. This proves the reliability of global climate change in the conditions of the Republic of Kazakhstan. The second gradation with an increase in air temperature by $1.1-2.0^{\circ} \mathrm{C}$, includes 2009, 2010, 2011, 2012 and 2014 (Table 2).

The obtained results of climate change rationale prove the general tendency of climate change which in conditions of our research can be characterized as "warming with increasing aridity". Of 12 years examined, 8 were dry (2006, 2007, 2008, 2009, 2014, 2015, 2016, 2017).

Thermal resources of summer in the zone are high, the average monthly temperature for July during the years of research was higher and amounted to $24.5-27.3^{\circ} \mathrm{C}$ with an average monthly long-term temperature of $24.1^{\circ} \mathrm{C}$.
The frequency of summer droughts during years of research increased markedly; 2006, 2007, 2008, 2016 and 2017 were especially arid, when significant precipitation did not fall in July and August and if they fell, they didn't amount even 5-8 $\mathrm{mm}$. The hot period can begin from the second decade of April and continue until the end of the growing season of the studied crops.

The average temperature of this period in particularly dry years was between +24.1 and $+27.3^{\circ} \mathrm{C}$. The average long-term annual temperature of the hottest month (July) was $+22.9-+25.9^{\circ} \mathrm{C}$. With an amplitude of diurnal fluctuations of day and night temperatures, it is high and averages more than $+20^{\circ} \mathrm{C}$.

While justifying the "climate-agriculture" system, we revealed that climate as a natural resource in all years of research changes, especially average daily air temperatures.

Climate warming in the south-east of Kazakhstan turned out to be noticeably larger than the global change, where the anomalies of average annual temperature during years of research reach 3 and $4^{\circ} \mathrm{C}$ (according to 2006 data, $3.5^{\circ} \mathrm{C}$ and 2017 data, $4^{\circ} \mathrm{C}$ ), while for the globe they only slightly exceed $1^{\circ} \mathrm{C}$ (Table 3 ).

The change in average daily annual air temperature during research years was $2.39^{\circ} \mathrm{C}$ with fluctuations from 1.1 to $4.1^{\circ} \mathrm{C}$. Greater warming within $1.6-3.0^{\circ} \mathrm{C}$ was observed in $2009\left(1.6^{\circ} \mathrm{C}\right), 2010\left(1.8^{\circ} \mathrm{C}\right), 2012\left(1.6^{\circ} \mathrm{C}\right)$, $2014\left(1.5^{\circ} \mathrm{C}\right)$ and $2016\left(2.6^{\circ} \mathrm{C}\right)$. The greatest warming at 3.1-4. $0^{\circ} \mathrm{C}$ distinguished 2006-2008 and 2013-2017).

Thus, in the years of study in the South-East of Kazakhstan, the change in the average daily air temperature was characterized as abnormal. In all 12 years of surveys, the air temperature was higher than the average annual level, of which 4 years the temperature exceeded the norm from 1.5 and $1.8^{\circ} \mathrm{C}$ and 8 years-from 2.1 to $4^{\circ} \mathrm{C}$, which indicates an abnormal situation and a high risk for the cultivation of the leading crops of the agricultural zone of South-Eastern Kazakhstan.

\section{Climate Change and Adapting to it Agro-Industrial Complex of Almaty Region}

The current state of climate change forecast may lead the southeast agrarian region to face completely unforeseen and severe restrictions in form of increased aridity of territories, which will lead to instability of the Almaty region's agrarian sector.

Agricultural productivity depends on the possible level of risk of changes in the frequency of adverse events (Bykova et al., 2014). The increase in the probability of low yields as a result of an increase in frequency and repeatability of droughts and increase in aridity identified by us over research years can be dangerous.

With existing climate changes in conditions of our research, considering the cultivation of leading oilseeds, we determined the environmental aspects of 
agroecosystem for growing soy. The ecological situation of the crop ecosystem, depending on climate change during research years related to the cultivation of oilseeds in terms of air temperature depends on the sowing season and duration of the growing season.

Soybean thermophilic culture sowing is carried out in the second and third decade of May and full ripeness occurs in September. The growing season of soybeans covers May-September. In this regard, the average daily $\mathrm{t}^{\circ} \mathrm{C}$ of air for the growing season in the years of study ranges from 18.7 (2009) to $23.5^{\circ} \mathrm{C}$ (2008).

During our research, growing season air temperature parameters changed; the average daily temperature due to prevailing weather conditions during all years of research changed with an increase in average daily air temperature within the range of 1.3 and $3.6^{\circ} \mathrm{C}$ compared to the longterm data $\left(19.9^{\circ} \mathrm{C}\right)$, except for 2 years. The ecological situation of crop ecosystem depending on climate change during years of research while cultivating oilseeds according to air temperature parameters is formed depending on sowing period, duration of the growing season and prevailing weather conditions (Table 4).

During research years, climate change when cultivating oilseeds, according to parameters of air temperature during the growing season, are related to prevailing weather conditions (Fig. 5).

Changes in air temperature under soybean sowing were characterized by an increase in average daily air temperature within the range of 1.3 to $3.6^{\circ} \mathrm{C}$ in comparison with long-term data $\left(19.9^{\circ} \mathrm{C}\right)$ (Table 4), except for 2 years (2009 and 2010).

Climate change entails a change in soil fertility. In dry years, agrophysical factors of the soil resource, such as aggregate composition and soil texture, deteriorate sharply. Correspondingly with the increase in air temperature, vegetation and productivity of the agroecosystem change. Changes in the climate system are recorded by fluctuations in surface air temperature (Sergeev, 2009), which is the main factoring local change in progressive climate warming within the scope of our research.

Therefore, in these new conditions, an important principle for the development of agricultural sectors should be the adaptation of crop cultivation technology to climate change. To adapt agriculture to climate change and make the agricultural sector of the Almaty region sustainable, we found it advisable to implement a set of measures, among which we studied measures to combat drought: Soil protection technologies,-minimizing the technological impact on soils and impact to resourcesaving technologies on oilseed productivity.

With resource-saving technology, with soil-protective flat cutting treatment intact, the thickness of the plant increases. Depending on an increase in average monthly daily air temperature by $2.70^{\circ} \mathrm{C}$ in 2015 and 2017 , applied soil-protective technologies showed significant positive effect on soybean yields (Table 5).

Table 2: Parameters for air temperature change in the conditions of southeast Kazakhstan (for 2006-2017)

\begin{tabular}{llll}
\hline Gradation \# & $\begin{array}{l}\text { Change of average daily air } \\
\text { temperature, drought }\end{array}$ & Research years & $\begin{array}{l}\text { Number of years with } \\
\text { temperature change }\end{array}$ \\
\hline 1-gradation & $\mathrm{t}^{\circ}$ increase for $1{ }^{\circ} \mathrm{C}$ & Air temperature change didn't exceed $1^{\circ} \mathrm{C}$. & \\
2-gradation & $\mathrm{t}^{\circ}$ increase for $1,1-2,0^{\circ} \mathrm{C}$ & $2009,2010,2011,2012,2014$ & 5 years out of 12 \\
3-gradation & $\mathrm{t}^{\circ}$ increase for $2,1-3,0^{\circ} \mathrm{C}$ & 2013 and 2016 & 2 years out of 12 \\
4-gradation & $\mathrm{t}^{\circ}$ increase for $3,1-4,0^{\circ} \mathrm{C}$ & $2006,2007,2008,2015,2017$ & 5 years out of 12 \\
\hline
\end{tabular}

Table 3: The impact of changes in mean annual air temperature on possible drought risk and soybean yields in South-Eastern Kazakhstan (in the years of study)

\begin{tabular}{lllll}
\hline \multicolumn{2}{c}{ Average yearly air } & & & \\
Research years & Cemperature, $\mathrm{t}^{\circ} \mathrm{C}$ & Climate warming, $\mathrm{t}^{\circ} \mathrm{C}$ & $\begin{array}{l}\text { Soybean yield in } \\
\text { years of research, c/ha }\end{array}$ & Potential risk \\
\hline 2006 & 11.2 & 3.5 & 19.5 & drought \\
2007 & 10.8 & 3.1 & 19.1 & drought \\
2008 & 10.8 & 3.1 & 19.3 & drought \\
2009 & 9.3 & 1.6 & 27.3 & - \\
2010 & 9.5 & 1.8 & 28.6 & - \\
2011 & 8.8 & 1.1 & 29.2 & - \\
2012 & 9.3 & 1.6 & 27.9 & drought \\
2013 & 9.8 & 2.1 & 18.6 & - \\
2014 & 9.2 & 1.5 & 23.9 & drought \\
2015 & 11.4 & 3.7 & 16.7 & drought \\
2016 & 10.3 & 2.6 & 17.1 & drought \\
2017 & 11.7 & 4.0 & 16.5 & \\
Average annual air & 7.7 & Average warming $\mathrm{t}^{\circ} \mathrm{C}=2.39$ & & \\
temperature, $\mathrm{t}^{\circ} \mathrm{C}$ & & & &
\end{tabular}


Table 4: Climate changes during years of research related to soy by air temperature parameters, $\mathrm{t}^{\circ} \mathrm{C}$

\begin{tabular}{lll}
\hline & $\begin{array}{l}\text { During the soybean growing season } \\
\text { Research years }\end{array}$ & \\
\hline 2006 & 21.2 & Changes in air $\mathrm{t}^{\circ} \mathrm{C}$ compared to multiple year data \\
2007 & 21.6 & +1.3 \\
2008 & 23.5 & +1.7 \\
2009 & 18.7 & +3.6 \\
2010 & 19.1 & - \\
2011 & 20.1 & - \\
2012 & 22.5 & +0.2 \\
2013 & 21.2 & +2.6 \\
2014 & 21.6 & +1.3 \\
2015 & 22.8 & +1.7 \\
2016 & 21.3 & +2.9 \\
2017 & 22.8 & +1.4 \\
Average monthly multy-year $\mathrm{t}^{\circ} \mathrm{C}$ & 19.9 & +2.9 \\
\hline
\end{tabular}

Table 5: The impact of changes in air temperature, $t^{\circ} \mathrm{C}$, on agroecosystem productivity under the resource conservation technology of soybean cultivation (in the years of study)

\begin{tabular}{|c|c|c|c|c|}
\hline \multirow[b]{2}{*}{ Technology } & \multirow[b]{2}{*}{ Research years } & \multicolumn{3}{|l|}{ Soy cultivation } \\
\hline & & $\begin{array}{l}\text { Average daily } \mathrm{t}^{\mathrm{o}} \mathrm{C} \text { during } \\
\text { the growing season }\end{array}$ & $\begin{array}{l}\text { Changes in air temperature, } \\
\text { compared to long-term } t^{\circ} \mathrm{C}\end{array}$ & Yield, c/ha \\
\hline \multirow{3}{*}{$\begin{array}{l}\text { Traditional technology- } \\
\text { plowing for } 20-22 \mathrm{~cm} \text { deep }\end{array}$} & 2016 & 21.3 & +1.4 & 25.8 \\
\hline & 2017 & 22.8 & +2.9 & 24.5 \\
\hline & Ave. & 19.9 & & 24.7 \\
\hline Resource- saving & 2015 & 22.8 & +2.9 & 29.1 \\
\hline \multirow[t]{3}{*}{ Flat-cut $16-18 \mathrm{~cm}$ herbicide } & 2016 & 21.3 & +1.4 & 27.7 \\
\hline & 2017 & 22.8 & +2.9 & 28.9 \\
\hline & Ave. & 19.9 & & 28.6 \\
\hline \multirow[t]{4}{*}{ Flat-cut $12-14 \mathrm{~cm}+$ impulse } & 2015 & 22.8 & +2.9 & 27.5 \\
\hline & 2016 & 21.3 & +1.4 & 27.6 \\
\hline & 2017 & 22.8 & +2.9 & 28.2 \\
\hline & Ave. & 19.9 & & 27.8 \\
\hline
\end{tabular}

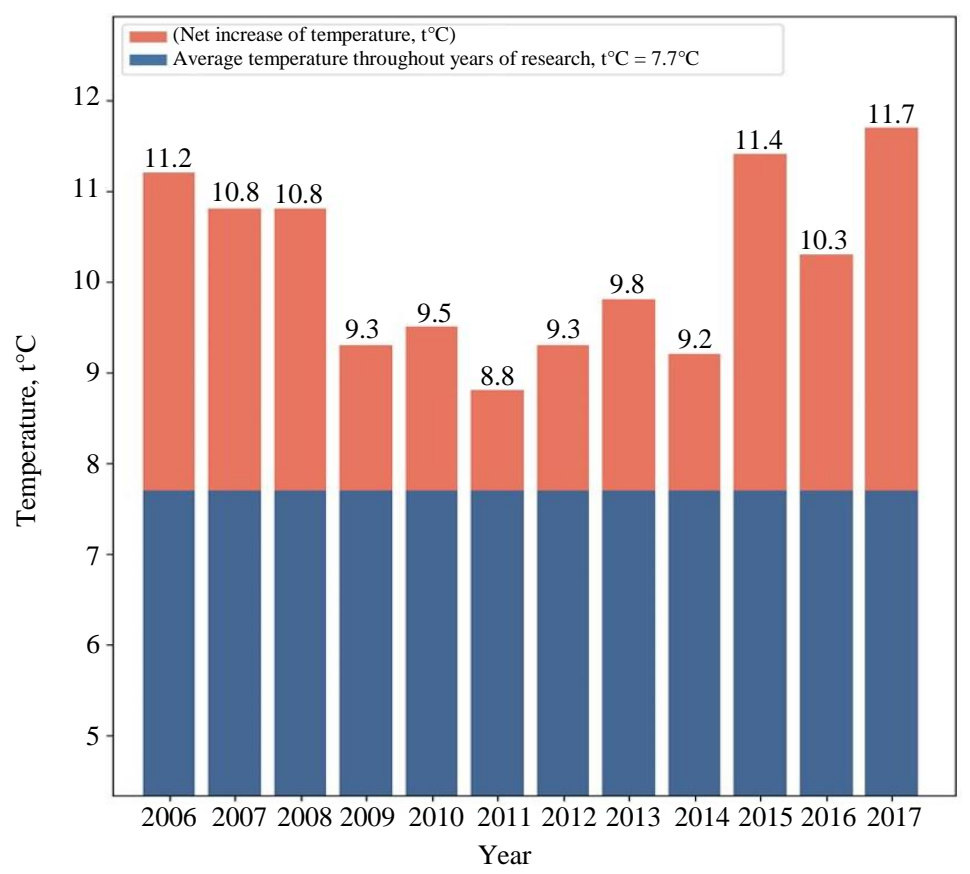

Fig. 4: Changes in average annual air temperature during research years in the southeast of Kazakhstan, $\mathrm{t}^{\circ} \mathrm{C}$ 


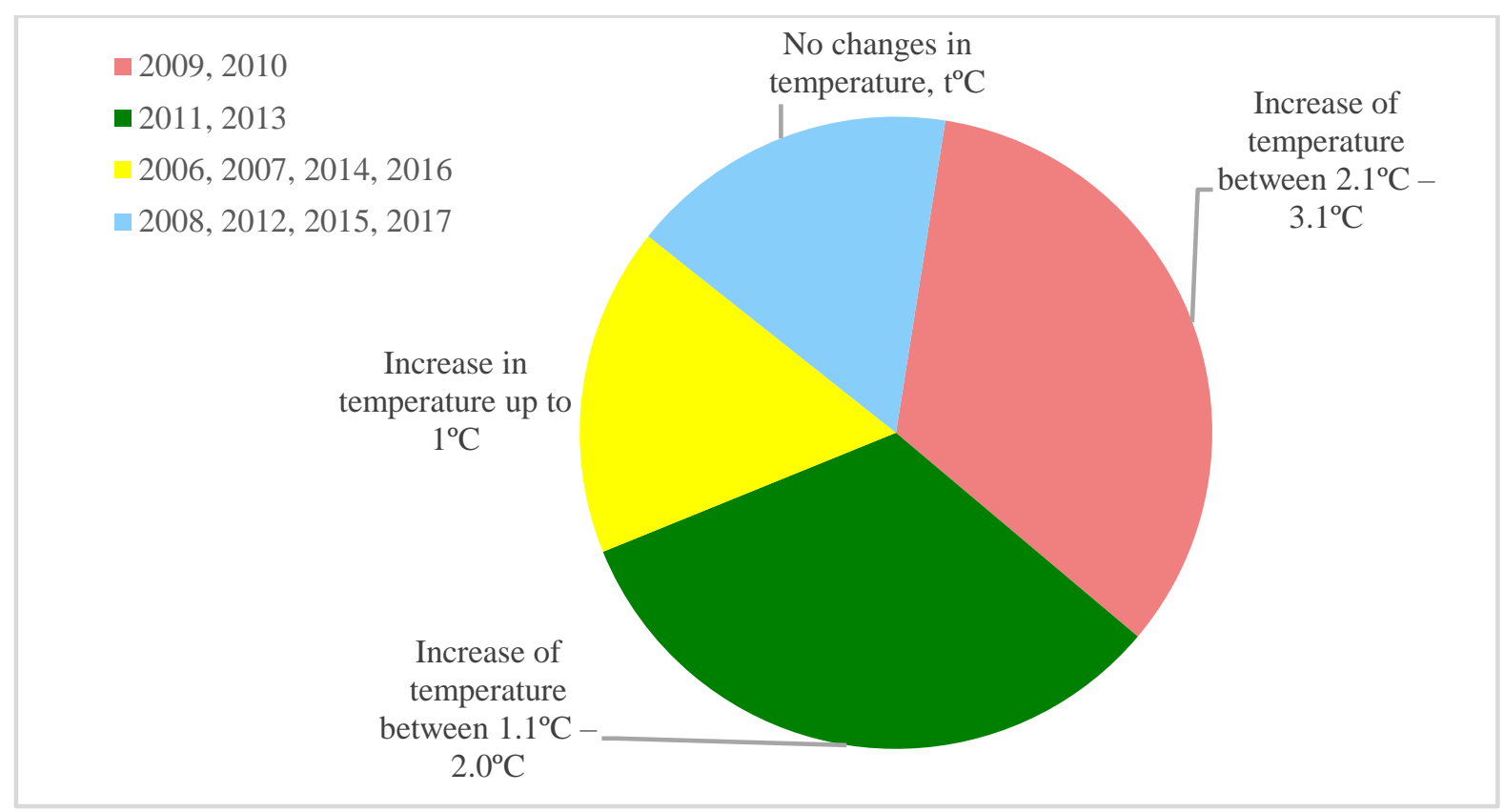

Fig. 5: Climate change when cultivating soy by air temperature parameters during research years

Cultivating soybean by using soil-preserving tillage of resource-saving technology, the condition of cultivating crops acquires a more positive environmental situation.

\section{Discussion}

The most important event in the 20th century is global warming, which has been evident since the late $1980 \mathrm{~s}$ (Plyusnin, 2013). This event has raised global environmental change under the influence of climate change as one of the fundamental problems of ecology. In the study of global climate warming, the main indicator is the change in average daily air temperature during a certain period of growth of the studied crop.

In the conditions of our study, the data obtained (Fig. 4) show a significant change in climatic conditions under the traditional technology of soybean cultivation.

The warming of the climate is a remarkable phenomenon as the value of average annual air temperature indicates a slight global change, where the anomaly of average annual temperature (reaches a maximum of 8.8 to $11.7^{\circ} \mathrm{C}$, which exceeds the long-term value $\left(7.7^{\circ} \mathrm{C}\right)$ ) shows the global warming of the climate in conditions of cultivation of the valuable leguminous crop, soybean.

The International Panel on Climate Change (Weart, 2008) has argued that global warming will soon become irreversible unless urgent action is taken. The change could start as soon as the average global surface temperature rises by $2^{\circ} \mathrm{C}$ in the next $10-20$ years (currently $0.8^{\circ} \mathrm{C}$ higher). In the conditions of our research, the average annual temperature of land surface during cultivation of soybean increased by $2-4^{\circ} \mathrm{C}$ in 8 years out of 12 years studied. This can be seen from the data presented in Table 3, where the impact of changes in mean annual air temperature on the possible risk of drought and soybean yields in the conditions of South-Eastern Kazakhstan was studied.

At present, scientists have noted that (Belolyubtsev and Sennikov, 2012; Burko and Tereshina, 2013) natural ecosystems are likely to undergo significant changes, which may cause irreversible losses in their ecosystems. Scientists (Iskakova, 2015; Onaev et al., 2012) have discovered that the results of the average global warming of $3.0^{\circ} \mathrm{C}$ can lead to a decrease in soil fertility and loss of biodiversity (Altaev and Imeskenova, 2017). According to expert estimates (Ivanov et al., 2004), the impact of global warming on the efficiency of agricultural production is ambiguous, with negative consequences combined with positive ones. Experts believe that an increase in the probability of low yields as a result of increased frequency of droughts and increased aridity in the territories of some agricultural regions may become particularly dangerous. The same pattern of low-yield probability is also observed in the years of our research with high warming. The change in mean annual air temperature during the years of research (Table 3 ) was $2.39^{\circ} \mathrm{C}$. During higher warming periods (5 years out of 12 ), when the average daily air temperature rises to 3.1 $4.1^{\circ} \mathrm{C}$ and soybean yields $20.1 \mathrm{c} / \mathrm{ha}$ and $17.5 \mathrm{c} / \mathrm{ha}$, respectively, where the productivity of agroecosystem drops to $21.8-30.1 \%$, with a sharp increase of drought frequency ( 7 years out of 12 studied years). Thus, in the years of the study in the territory of south-eastern 
Kazakhstan, the change in average daily air temperature was at risk and was characterized by abnormal mean annual temperature. In all years of the 12-year survey, the air temperature was above the average annual level, of which 4 years exceeded the norm temperature of 1.5 and $1.8^{\circ} \mathrm{C}$ and 8 years from 2.1 to $4^{\circ} \mathrm{C}$, indicating an anomalous situation and high risk for growing soybeans in the agricultural zone of south-eastern Kazakhstan.

The results of the justification of climate change prove the general trend of climate change in the conditions of our study and can be characterized as "warming with increasing aridity".

Based on the four-dimensional gradation (Suleimenova et al., 2020), climate change over 12 years of studies with an increase in air temperature of more than $1^{\circ} \mathrm{C}$ revealed that in all years of the study, the change in air temperature exceeded $1^{\circ} \mathrm{C}$, i.e., there was not a single year where the typical long-term average air temperature in the study area was not exceeded, which proves the reliability of global climate change in the Republic of Kazakhstan.

The reality of climate change and changing conditions of agriculture requires the development of technology for the adaptation of the agricultural sector and its sustainable development under new conditions. Belkov's research suggested the need for further scientific research to identify predictable climate change in agricultural areas (Belkov, 2011).

Therefore, under these new conditions, it is important to adapt the cultivation technologies of the soybean crop under study to climate change. To adapt the agroecosystem of soybean, it is advisable to use soilprotecting technologies while minimizing the technogenic impact of main moldboard tillage. It is possible by means of using boardless plowing cultivation KPP-2.2 instead of plowing PN-4-35, which ensures restoration of agrophysical factors of soil fertility, where the coefficient of structure increases from 0.65 to $0.87-0.89$ on average, which indicates a good soil structure.

Thus, it is revealed that during traditional technology (moldboard plowing), the top 0-30 $\mathrm{cm}$ layer of soil is loosened to the maximum (bulk weight-0.9-1.11 g/ $/ \mathrm{cm}^{3}$ ), where the water-air regime of soil worsens. The resource conservation technology of soybean cultivation with soilprotection technology (Mini-till) ensures the sustainability of the ecological state of the soil environment, improves the structure and increases the water-resistance of soil aggregate of the agroecosystem. The structure of the arable soil layer is stabilized, which contributes to the normal growth and development of the crop. Soil-protective technology of cultivation is the leading agricultural practice ensuring preservation and increase of qualitative and quantitative indicators of soil resources.

Thus, the expediency of resource conservation technology of the cultivation of soybean is revealed. The net profit from the application of rational resource conservation practices proves that the passage of tillage machines is reduced in half due to which the cost of cultivation is reduced and the level of profitability of cultivation is increased from 74.8 to $113.7 \%$. The restoration of agrophysical parameters of soil fertility is determined, where the cost of total energy is reduced to $22.7-28.9 \%$ (economical consumption of fuel) due to reducing the number of combustible materials and lubricants for the minimum treatment with resource conservation technology. It is established that the application of resource conservation technology provides receiving 31.7 thousand tenges/ha of additional income from each hectare of soybean.

Based on the obtained results, the efficiency of soilprotective methods of soybean cultivation technology depending on the influence of the emerging climatic conditions in the years of research was determined.

The improvement of ecological conditions of soybean agrophytocenosis depending on the application of soil-protective methods of crop technology, which mitigate the risk of drought in years with increased temperature, was revealed.

It provides optimal growth and development of crops with the increase of productivity of soybean. Depending on the increase in average monthly daily air temperature by $2.7^{\circ} \mathrm{C}$ in 2015 and 2017 , the applied soil-protective technologies had a positive significant impact on soybean yields (Table 5).

The application of minimum tillage technology increases the stability of the ecological state of the soil and provides stabilization of the structure of the arable (0-30 $\mathrm{cm})$ soil layer, where the soil density is within 1.20-1.27 $\mathrm{g} / \mathrm{cm}^{3}$ the optimal value for normal growth and development of soybean crop (Table 5).

In the years of the study, the initial growing season of soybean development in 2015-2017 was characterized by high moisture, where a complex ecophytosanitary situation was created, where the structure of agrophytocenosis was characterized by an increased proportion of weed component.

With such a high abundance of weeds on the ecosystem of soybean phytocenosis, the efficiency of resource conservation technology on the background of boardless plowing tillage and the use of innovative measures to combat weed infestation on the fields has increased and created optimal environmental conditions that ensure high enough soybean productivity.

The application of optimal eco-friendly dosage of herbicides on the background of minimum tillage gives the maximum effect; the number of weeds is reduced to 25.8-31.8 $\mathrm{pcs} / \mathrm{m}^{2}$, creating optimal environmental conditions for the growth and development of soybeans.

With soil-protective treatment of technology of soybean cultivation in droughty years, the emerging optimum conditions for growth and development of the crop reduce the depressing effects of climate change and 
provide the increase of soybean yield to 28.9-29.1 c/ha (on average by $23.8 \%$ ) during the change of the average daily temperature of the vegetation period at sowing by $2.9^{\circ} \mathrm{C}$.

The obtained results indicate the adaptation of soybean cultivation conditions to this situation of global climate and environmental changes in the agroecosystem of South-Eastern Kazakhstan.

\section{Conclusion}

The following conclusions can be drawn from the results:

1. At present, due to the crisis phenomenon of the impact of climate change in the conditions of southeastern Kazakhstan on the cultivation of valuable grain legume and oilseed crop soybean, the ecological situation of the ecosystem is established and the phenomenon that harms the formation of soybean agrophytoceosis is revealed. The change of climatic parameters by average annual air temperature by months in 2006-2017 was estimated. Obtained results are characterized by maximum values and vary from year to year in the range of 8.8 to $11.7^{\circ} \mathrm{C}$. At the same time, the air temperature for the years of research exceeds the long-term average annual temperature value $\left(7.7^{\circ} \mathrm{C}\right)$ by 3 and $4^{\circ} \mathrm{C}$

2. The climate warming results indicate a notable phenomenon that corresponds to the global climate change of the study area of the southeast of Kazakhstan. Identified high abnormal annual average temperature in the range of 1.1 to $4.1^{\circ} \mathrm{C}$ causes concern and indicates the possibility of low yields of the soybean crop as a result of high-temperature impacts, increased aridity, frequency, recurrence and risks of drought. This requires innovative development-effective resource conservation technologies of soybean crop cultivation. Under a warming climate (by $1.1-2.1^{\circ} \mathrm{C}$ ), soybean yields are 25.2-18.6 c/ha. At climate warming between $3.1-4.1^{\circ} \mathrm{C}$, yields are $17.5-19.5$ t/ha respectively, decreasing by $25.0-31.0 \%$

3. The expediency of the resource conservation technology with the soil-protecting method at minimum tillage is revealed. It ensures the sustainability of the ecological state of the soybean agroecosystem, where the agrophysical factors of soil fertility are improved and the optimum conditions for growth and development of soybean with an increase of crop productivity are created

4. Based on the results, the ecological (preservation and restoration of soil resources) and economic efficiency of agroecosystem of soil-protective techniques of the cultivation technology for soy was determined depending on the influence of emerging climatic conditions for 2015-2018
The improvement of ecological conditions of soybean agrophytocenosis was revealed depending on the application of soil-protective practices, which mitigate the risk of drought in years with elevated temperatures. The practices provide optimal crop growth and development with an increase in soybean productivity of up to $23.8 \%$.

\section{Author's Contributions}

All authors equally contributed in this study.

\section{Ethics}

This article is original and contains unpublished material. The corresponding author confirms that all other authors have read and approved the manuscript and no ethical issues have been involved.

\section{References}

Altaev, A. A., \& Imeskenova, E. G. (2017). Biodiversity: the textbook for self-study. BGSKhA after V. R. Filippov Publishing, Ulan-Ude. http://www.bgsha.ru/files/docs/Oms/BiodiversityBSAA.pdf

ARWFRI. (2011). Scientific research program and methodology (according to the International Coordination Programme of Research and Development of the Russian Agricultural Academy for 2011-2015). FGU RTsSK, Moscow. All-Russian Williams Fodder Research Institute. https://www.vniikormov.ru/pdf/programma-imetodika-provedeniya-nauchnyh-issledovanij-polugovodstvu.pdf

Bautin, V. M. (2011). Proceedings of the International scientific and practical conference "Adaptation of Russian agriculture to changing weather and climate conditions", December 7-11, 2010. Publishing House of the Russian State Autonomous University ICCA, Moscow. ISBN-10: 978-5-9675-0459-4.

Belkov, G. I. (2011). Proceedings of the international scientific-practical conference "Innovation and modernization of agricultural production in a changing climate". GNU Orenburg, SRI of Agr. of RAAS, Orenburg. http://www.cnshb.ru/Vexhib/rsh/11_10316.pdf

Belolyubtsev, A. I., \& Sennikov, V. A. (2012). Bioclimatic potential of agroecosystems. RGAU MSKhA, Moscow. ISBN: 978-5-9675-0642-0.

Bobyleva, S. N., Kiryushina, P. A., \& Kudryavtseva, O. V. (2019). The green economy and goals of sustainable development for Russia: a collective monograph. Ekonomicheskii fakultet MGU imeni M. V. Lomonosova, Moscow. ISBN-10: 978-5-906932-32-7. 
Burko, R. A., \& Tereshina, T. V. (2013). Ecological problems of modern society and their solutions. Young scientist, (11), 237-238.

Bykova, A., Malceva, N., Pavlova, D., Subbotina, M., Soklakova, O., \& Lukashova O. (2014). Effects of climate change on agriculture. Proceedings of the XIV int. scientific-practical conf. No. 13 "Natural and mathematical sciences in modern world". SibAK, Novosibirsk. https://sibac.info/conf/naturscience/xiv/36324

Cline, W. R. (2007). Global Warming and Agriculture: Impact Estimates by Country. Center for Global Development and Peterson Institute for International Economics, Washington. https://www.cgdev.org/publication/9780881324037global-warming-and-agriculture-impact-estimatescountry

Dronin, N. M. (2014). Climate Change and Russia's Food Security: A Historical Analysis and Model Forecasts. GEOS, Moscow. ISBN-10: 978-5-89118-665-1.

Eleshev, R. E. (2014). Workshop on agrochemistry. Al'manakh, Almaty. ISBN-10: 978-601-241-312-0.

FSAR. (2005). Recommendations. The farming system of the Almaty region. TOO «NurlyAlem», Almaty.

Gritsyuk, P. M. (2010). Analysis, Modeling and Forecast of the Dynamics of the Crop Yield of Winter Wheat over Ukraine's Regions. NUWEE, Rivne. https://lib.oa.edu.ua/files/funds/works_oa/economy/ Gricjuk\%20Anal\%D1\%96z,\%20modeljuvannja.pdf

Gritsyuk, P. M., \& Bachishina, L. D. (2016). The impact of changes in climatic conditions on the dynamics of grain yields in Ukraine. Scientific journal "Economics of Ukraine", 6(647), 68-75. http://irbisnbuv.gov.ua/cgi-

bin/irbis_nbuv/cgiirbis_64.exe?C21COM=2\&I21D

$\mathrm{BN}=\mathrm{UJRN} \& \mathrm{P} 21 \mathrm{DBN}=\mathrm{UJR} N \& I M A G E \_F I L E \_D O$

WNLOAD=1\&Image_file_name=PDF/ekukrr_2016 6_7.pdf

Gruza, G. V., \& Rankova, E. Ya. (2003). Oscillations and climate change in Russia. News of the Russian Academy of Sciences, 2(39), 166-185. ISSN: 0002-3515.

Iskakova, A. K. (2015). Contemporary issues of climate change. Journal of Occupational Hygiene and Medical Ecology, 1(46), 11-20. https://clck.ru/SPeWH

Israel, Yu. A. (2002). What kind of weather to expect on Earth? Science and Life, 1, 2-9. https://www.nkj.ru/archive/articles/3797/

Ivanov, A. L., Sirotenko, O. D., \& Aleksakhin, R. M. (2004). Global manifestations of climate change in agricultural sector. Russian Agricultural Academy, Moscow. ISBN-10: 5948730298.
Ivanov, V. A. (2008). Methodological basics of agrarian and industrial complex innovative development. Economic and Social Changes: Facts, Trends, Forecast, 2, 17-19. http://esc.vscc.ac.ru/article/23?_lang=en

Ivanova, A. L., Kiryushina, V. I. (2009). Global climate change and forecast of risks in Russian agriculture. Moscow, Rossel'khozakademiya. ISBN-10: 978-585941-334-8.

Kattsov, V. M., Kobysheva, N. V., Meleshko, V. P., Porfiryev, B. N., \& Revich, B. A. (2011). Evaluation of the macroeconomic consequences of climate change in the Russian Federation for the period up to 2030 and the future perspective. RIF "D'ART", Moscow. ISBN-10: 978-5-905264-04-7.

Kenenbaev, S. B., Yelnazarkyzy, R., Kalashnikov, P. A., \& Didorenko, S. V. (2019). The effect of irrigation regimeon the yield of soybean in the South and South-East of Kazakhstan. News of the National Academy of Sciences of the Republic of Kazakhstan. Series of Agricultural Sciences, 3(51), 20-26. https://doi.org/10.32014/2019.2224-526X.30

Kiryushin, B. D., Usmanov, P. P., \& Vasiliev, I. P. (2009). Fundamentals of scientific research in agronomy. Kolos, Moscow. ISBN-10: 978-5-9532-0497-2.

Kiselev, A. (2019). How the climate is changing. Farmers getting used to weather anomalies. Agroinvestor, 9, 145-159. https://www.agroinvestor.ru/agroinvestor/9940/

Kulistikova, T. (2019). The weather is getting nervous. How global climate change is affecting agriculture Agroinvestor, https://www.agroinvestor.ru/analytics/article/32343pogoda-stanovitsya-nervnoy/

Lukomets, V. M. (2007). The methodology of conducting field agrotechnical experiments with oilseeds. VNIIMK, Krasnodar. https://vniimk.ru/press/scientificpublication/metodika-provedeniya-polevykhagrotekhnicheskikh-opytov-s-maslichnymikulturami-2007-g/

Novikov, A. M., \& Novikov, D. A. (2010). Methodology of scientific research. Librocom, Moscow. ISBN-10: 978-5-397-00849-5.

Onaev, S. T., Ismailova, A. A., Kurmangalieva, D. S., Shadetova, A. Zh. Balaeva, E. A., Shalova, M. K., \& Tsenova, G. D. (2012). Climatic features of the transition period in Ekibastuz. Occupational Hygiene and Medical Ecology, 4, 107-109.

Perevedentsev, Y. P., Vereshchagin, M. A., Shantalinsky, K. M., Naumov, E. P., \& Khabutdinov, Y. G. (2011). Changes in climatic conditions and resources of the Middle Volga. Manual on regional climatology: a training. Center for Innovative Technologies, Kazan. ISBN-10: 978-5-93962-485-5. 
Plyusnin, Y. M. (2013). Climate change and its impact on human life. Guidance on the organization and implementation of climate change and their impact on nature management. Scientific World, Moscow. ISBN-10: 978-5-91522-332-4.

Polyanskaya, N. A., \& Polyanskiy, M. V. (2014). The impact of climate change on grain production in Russian Federation. Modern problems of science and education, 5, 383. https://www.scienceeducation.ru/ru/article/view?id=14886

Popytchenko, L. M. (2009). Weather and climatic conditions of the growing season of winter wheat in farms of Lugansk region, in: Collection of Scientific Works of Lugansk National Agrarian University, series "Agricultural Sciences". Lugans'k, Elton, 100, 121-124.

QazaqZerno. (2020). Climate change is one of the main threats to Kazakhstan's agricultural sector. Agrarian News of Kazakhstan. https://kazakhzerno.net/126651-izmenenie-klimata-odna-izglavnykh-ugroz-dlya-agrarnogo-sektorakazakhstana/

Saparov, A. (2014). Soil resources of the Republic of Kazakhstan: current status, problems and solutions. In Novel measurement and assessment tools for monitoring and management of land and water resources in agricultural landscapes of Central Asia (pp. 61-73). Springer, Cham. ISBN-10: 978-3-319-01016-8.

Schwartz, E. A., \& Kokorin, A. O. (2001). WWF Project on Effects of Climate Change on Ecosystems. In: The Impact of Climate Change on Ecosystems, Kokorin, A.O., A.V. Kozharinov and A.A. Minin, (Eds.), Russkiy universitet, Moscow, 1-4. ISBN-10: 589932-024-9.

Sergeev, K. (2009). Global climate change: the problem of sustainable agricultural development. Materials from collective monograph "Sustainability of Agriculture and Risks in the Context of Climate Change". Agriculture, 2(3), 44-45.

Shelamova, N. A. (2013). The impact of climate change on agriculture. Overview. Vniieskh, Moscow. ISBN10: 978-5-88371-049-9.
Solomon, S., Qin, D., Manning, M., Chen, Z., Marquis, M., Averyt, K. B., Tignor, M., \& Miller, H. L. (2007). Climate Change 2007. The Physical Science Basis. Contribution of Working Group I to the Fourth Assessment Report of the Intergovernmental Panel on Climate Change. Cambridge, New York. ISBN10: 9780521 88009-1.

Suleimenova, N. S., Kalykov, D. B., Filipova, M., \& Orynbasarova, G. (2020). Climate change and escalation of agroecosystem's ecological problems. Seriâ Agrarnyh Nauk, 44. https://doi.org/10.32014/2020.2224-526X

Suleimenova, N. Sh., Filipova, M., \& Kalykov, D. (2017). Features of climate change and the impaction the functioning of the agro-industial complex south-east of Kazakhstan. Proceedings of University of Ruse, 56(1.2), 125-128.

Suleimenova, N., Makhamedova, B., Orynbasarova, G., Kalykov, D., \& Yertayeva, Z. (2019). Impact of Resource Conserving Technologies (RCT) on soil physical properties and rapeseed (Brassica napus L.) yield in irrigated agriculture areas of the SouthEastern Kazakhstan. Eurasian Journal of soil Science, 8(1), 289-301. https://doi.org/10.18393/ejss.510686

Volodin, E. M., Diansky, N. A., \& Gusev, A. V. (2013). Reproduction and forecast of climatic changes in the 1921 centuries using the model of the Earth's climate system. Bulletin of the Russian Academy of Sciences. Physics of the Atmosphere and the ocean, 4, 379-400. https://doi.org/10.7868/S000235151304010X

Weart, S. R. (2008). The Discovery of Global Warming. Harvard University Press, Cambridge, MA and London, England, https://doi.org/10.4159/9780674417557

Yelnazarkyzy, R., Kenebayev, S. B., Didorenko, S. V., \& Borodychev, V. V. (2019). Soy Cultivation Technology with Gravity Drip Irrigation in South and Southeast Kazakhstan. Journal of Ecological Engineering, 20(7), 39-44. https://doi.org/10.12911/22998993/109862 